\title{
A re-evaluation of antibiotic sterilisation of heart valve allografts
}

\author{
W. H. WAIN, HELEN M. PEARCE, R. W. RIDDELL, AND D. N. ROSS
}

From The National Heart Hospital (National Heart and Chest Hospital Group), Westmoreland Street, London WIM $8 B A, U K$

Wain, W. H., Pearce, Helen M., Riddell, R. W., and Ross, D. N. (1977). Thorax, 32, 740-742. A re-evaluation of antibiotic sterilisation of heart valve allografts. Six different mixtures of antibiotics used for treating heart valve allografts at the National Heart Hospital have been compared and the formulation of the medium in current use is described. The abilities of antibiotic-resistant bacteria, and of fungi with low sensitivities to antifungal agents, to survive treatment are also described. These abilities emphasise the need for routine microbiological screening of every valve.

A mixture of antibiotics for the sterilisation of valve allografts was first described by BarrattBoyes and Roche (1969). Other mixtures have since been described (for example, Lockey et al., 1972; Yacoub et al., 1973; Waterworth et al., 1974). At the National Heart Hospital six different mixtures have been used to treat heart valve allografts over the past seven years. The Barratt-Boyes formula (1969) was found to be unsuitable, and Lockey et al. (1972) formulated an alternative mixture, ' $B$ ', which was used for three years and was then changed to the mixture ' $C$ ' described by Waterworth et al. (1974). This mixture, like that of Yacoub and Kittle (1970), was developed on the basis of extensive tests with selected, typical, contaminating microorganisms, for example, Staphylococcus aureus, Streptococcus faecalis, Escherichia coli, Pseudomonas aeruginosa, Proteus spp. and Klebsiella spp. The failure in use of mixture ' $C$ ' of Waterworth et al. (1974) necessitated a change to another proven formulation. This was the mixture described by Yacoub et al. (1973), which was providing satisfactory antimicrobial treatment at the Harefield Hospital, Middlesex.

The Harefield Hospital formulation was modified in January 1976 by using nystatin in place of amphotericin $B$, and this medium was given the acronym HANYNM (Harefield antibiotics with nystatin in nutrient medium). However, these high concentrations of antibiotics were deleterious to the valve tissue. It was decided to rationalise HANYNM by reducing the concentrations of all the antibiotics to a value approximately 100 times the minimum inhibitory concentration (MIC) quoted by Garrod et al. (1973) for $E$. coli,

Table 1 Composition (grams per litre) of different antibiotic mixtures used at the National Heart Hospital 1970-77

\begin{tabular}{|c|c|c|c|c|c|c|c|}
\hline Mixture & $\begin{array}{l}\text { Barratt-Boyes } \\
\text { (1969) }\end{array}$ & $\begin{array}{l}\text { Lockey } \\
\text { (1972) }\end{array}$ & $\begin{array}{l}\text { Waterworth } \\
\text { (1974) }\end{array}$ & $\begin{array}{l}\text { Yacoub } \\
(1973)\end{array}$ & $H A N Y N M$ & $N Y D A N M$ & $D A N Y N M$ \\
\hline $\begin{array}{l}\text { Benzyl penicillin } \\
\text { Methicillin }\end{array}$ & 0.03 & $10 \cdot 00$ & $1 \cdot 00$ & & & & \\
\hline $\begin{array}{l}\text { Carbenicillin } \\
\text { Cephaloridine } \\
\text { Neomycin }\end{array}$ & & & & $\begin{array}{r}10 \cdot 00 \\
10 \cdot 00 \\
5.00\end{array}$ & $\begin{array}{r}10 \cdot 00 \\
10 \cdot 00 \\
5 \cdot 00\end{array}$ & $\begin{array}{r}10.00 \\
0.04 \\
1.00\end{array}$ & $\begin{array}{r}10.00 \\
0.04 \\
1.00\end{array}$ \\
\hline Kanamycin & 1.00 & & & & & & \\
\hline Gentamicin & & $4 \cdot 00$ & 1.00 & & & & \\
\hline $\begin{array}{l}\text { Streptomycin } \\
\text { Erythromycin }\end{array}$ & $1 \cdot 00$ & $6 \cdot 00$ & & & & & \\
\hline Polymixin B & & & 0.01 & $0 \cdot 70$ & 0.70 & 0.70 & 0.70 \\
\hline Nystatin & & 0.50 & 0.50 & & 0.50 & 0.10 & 0.50 \\
\hline Amphotericin B & 0.025 & & & $0 \cdot 25$ & & & \\
\hline
\end{tabular}


Ps. aeruginosa, Staph. aureus, and Candida albicans. This weaker medium was given the acronym NYDANM (nystatin with dilute antibiotics in nutrient medium).

\section{Material and methods}

Table 1 presents the formulation of the different antibiotic mixtures described above. In order to test the effectiveness of the dilute mixture, NYDANM, it was compared with HANYNM in parallel tests on contaminated tissues from 100 valves. In the routine microbiological screening of the valve three pieces of the aortic wall, $10 \times 3 \mathrm{~mm}$, were trimmed from the prepared allograft valve and incubated for at least 24 hours at room temperature in $30 \mathrm{ml}$ of the antibiotic medium, HANYNM or NYDANM. After 24 hours the three pieces of tissue were removed aseptically from each medium and allowed to drain. These pieces were cultured in glucose broth, Brewer's medium, and Sabouraud's broth, and subcultured on to appropriate solid media after three and six days. If no growth was detected in any of these cultures after nine days the treatment was regarded as effective.

\section{Results and discussion}

Table 2 illustrates the effectiveness recorded for the different antibiotic mixtures during a six-year period. Lockey et al. (1972) have previously reported the results for the Barratt-Boyes (1969) mixture. Table 2 extends the results of solution ' $B$ ' (Lockey et al., 1972) from 1972 to 1974 . The introduction in 1974 of mixture ' $C$ ' of Waterworth $e t$ al. (1974) unfortunately coincided with their recommended cessation of sterility testing. Therefore there were no results for the effectiveness of mixture ' $C$ ' until 1975 , when the mixture failed in use. A total of 196 valves had been treated with mixture ' $\mathrm{C}$ ' and of those at least 55 were contaminated.

At the National Heart Hospital the use of

Table 2 Effectiveness of different antibiotic mixtures

\begin{tabular}{lllrl}
\hline $\begin{array}{l}\text { Date } \\
\text { of use }\end{array}$ & Mixture & $\begin{array}{l}\text { No. of } \\
\text { valves } \\
\text { treated }\end{array}$ & $\begin{array}{l}\text { Growing } \\
\text { fungi }\end{array}$ & $\begin{array}{l}\text { Growing } \\
\text { bacteria }\end{array}$ \\
\hline 1970 & Barratt-Boyes & 66 & $8(12 \%)$ & $23(35 \%)$ \\
1971 & Lockey & 416 & $10(2 \%)$ & 0 \\
1974 & Waterworth & 196 & $55(28 \%)$ & $55(28 \%)$ \\
1975 & Yacoub & 230 & $35(15 \%)$ & 0 \\
1976 & HANYNM & 233 & $5(2 \%)$ & 0 \\
1976 & NYDANM & 100 & $13(13 \%)$ & $2(2 \%)$ \\
1976 & DANYNM & 150 & $2(1 \%)$ & $3(2 \%)$ \\
\hline
\end{tabular}

amphotericin B (Yacoub et al., 1973) was not satisfactory in controlling fungal contamination, the incidence of which was $15 \%$ (Table 2). At the Harefield Hospital the valves are kept in the antibiotic mixture of Yacoub et al. (1973) for 24 hours and then transferred for subsequent storage to a nutrient medium containing nystatin (Yacoub, personal communication). The elective omission of this transfer step to nystatin was an obvious contributory factor to the $15 \%$ withdrawal rate presented in Table 2. HANYNM (Table 1) has proved satisfactory with the replacement of amphotericin B by nystatin (Table 2). Table 2 shows that although NYDANM was effective in controlling contaminating bacteria, the lower concentration of nystatin $(0.1 \mathrm{~g} / 1)$ in NYDANM was not effective in controlling fungal contamination. For this reason the medium was changed to DANYNM (dilute antibiotics with nystatin in nutrient medium) (Table 1), in which the high concentration of nystatin in HANYNM $(0.5 \mathrm{~g} / 1)$ was used. DANYNM is now in routine use at the National Heart Hospital for the treatment of heart valve allografts and has given only a $3 \%$ rate of withdrawal. This medium still has a high cytotoxic level of nystatin. The concentrations of the antibiotics have been reduced to a rational level, avoiding some cytotoxicity (eg, from cephaloridine). It is estimated that the change from HANYNM to DANYNM will save $£ 1000$ per annum in the treatment of 300 heart valves. This combination of antibiotics retains its antibacterial effectiveness during seven days' storage at $+4^{\circ} \mathrm{C}$.

The other important issue which was raised by the failure of the mixture described by Waterworth et al. (1974) was the absolute necessity for routine microbiological screening. Waterworth et al. (1974) correctly pointed out that such screening was misleading in view of the carry-over of antibiotics from the sterilising mixture to the bacteriological growth medium. However, the tests of Waterworth et al. (1974) detected organisms resistant to their mixture ' $C$ ' of antibiotics. Also, at the National Heart Hospital, strains of Pseudomonas spp resistant to both gentamicin and polymyxin were seen as cloudy growths in media containing valves treated with the same antibiotic mixture ' $C$ '. Because of this resistant contamination many valves in the Waterworth et al. (1974) mixture ' $C$ ' were discarded (Table 2). The simultaneous occurrence of contaminating fungi in the Waterworth et al. (1974) mixture 'C' (Table 2) was surprising in view of the effectiveness of the same concentration of nystatin $(0.5 \mathrm{~g} / 1)$ in HANYNM. It is, of course, possible that one or 
more of those fungi had a low sensitivity to nystatin, but this was not investigated at that time.

The re-introduction of routine microbiological screening of heart valve allografts in this hospital has resulted in the withdrawal prior to clinical use of a number of valves: 35 of 230 valves treated with the Harefield antibiotic mixture (described by Yacoub et al. (1973)), 5 out of 233 valves treated with HANYNM, and 5 out of 150 valves treated with DANYNM (Table 2). Forty-two of these 45 withdrawals were due to the presence of fungi on the valve tissue. Two isolates of Candida species proved to be peculiarly resistant to the antifungal agent, nystatin, without any prior exposure to the drug. The MIC of this drug for these two particular isolates was $0.025 \mathrm{~g} / 1$ yet they survived treatment in a medium containing $0.5 \mathrm{~g}$ nystatin per litre (HANYNM). Three withdrawals were due to bacterial contamination. These were: one Strep. faecalis, resistant to polymyxin, neomycin, and cephaloridine; one coliform bacillus, resistant to carbenicillin and cephalothin; and one Grampositive coccus, the identification tests and sensitivities for which were not carried out.

We therefore wish to emphasise the importance of routine microbiological screening of heart valve allografts, or any other tissues for clinical use, which have been treated with high concentrations of antibiotics. This emphasis is in direct conflict with the views of Waterworth et al. (1974) but reinforces the doubts of Lockey (1975); '. . . the author does not think that antibiotics can be relied upon unfailingly to sterilise homograft tissues'. However, provided that there is adequate microbiological testing of each valve, high concentrations of antibiotics may be used as one way of treating heart valves intended for surgery, and we propose to continue to use this method.

We thank the Clinical Research Committee of the National Heart and Chest Hospitals and the British
Heart Foundation for grants in support of this work. We also acknowledge the donations of drugs from Beecham Pharmaceuticals, Glaxo Laboratories Ltd, E. R. Squibb and Sons Ltd, Upjohn Ltd, and Wellcome Foundation Ltd. We are grateful to Ms R. A. Bennett and Mrs P. N. V. $\vec{\circ}$ Smith for help in providing the valves and to $\mathrm{Ms}$ S. G. McClymont for technical assistance.

\section{References}

Barratt-Boyes, B. G., and Roche, A. H. G. (1969). A review of aortic valve homografts over a six and one-half year period. Annals of Surgery, 170, 483492.

Garrod, L. P., Lambert, H. P., and O'Grady, F. (1973). Antibiotic and Chemotherapy, 4th edition. Churchill Livingstone, Edinburgh.

Lockey, E. (1975). Problems of sterilisation in homograft preparation. In Current Status of Cardiac Surgery, edited by D. B. Longmore, pp. 215-218. Medical and Technical Publishing, Lancaster.

Lockey, E., Al-Janabi, N., Gonzalez-Lavin, L., and Ross, D. N. (1972). A method of sterilizing and preserving fresh allograft heart valves. Thorax, 27, 398-400.

Waterworth, P. M., Lockey, E., Berry, E. M., and Pearce, H. M. (1974). A critical investigation into the antibiotic sterilization of heart valve homografts. Thorax, 29, 432-432.

Yacoub, M., and Kittle, C. F. (1970). Sterilization of valve homografts by antibiotic solutions. Circulation, 41/42, Supplement 2, 29-31.

Yacoub, M., Knight, E. J., and Towers, M. (1973). Aortic valve replacement using fresh unstented homografts. Thoraxchirurgie, 21, 451-457.

Requests for reprints to: Dr. W. H. Wain, Homograft Department, National Heart Hospital, Westmoreland Street, London W1M 8BA, UK. 